\title{
The Development of Guided Inquiry-Oriented Guides for Plant Morphology Biology Education Practicum Students of IPTS Padangsidimpuan
}

\author{
Rosniati $^{1 *}$, Lufri Lufri ${ }^{1}$ \\ ${ }^{1}$ Biology Department, Math and Natural Science Faculty, Universitas Negeri Padang, Padang, Indonesia \\ *Corresponding author. Email: rosniati1983ajah@gmail.com
}

\begin{abstract}
The aims of this study was to describe of effective of plant morphology practicum guide book was oriented guided inquiry at the third semester of students of Biology Department of IPTS Padangsidimpuan. This type of research is the development of research. The development models used in this study is the Plomp models with 24 students as samples and they are taken using total sampling techniques. The instruments used were student learning motivation questionnaires, observation sheets of student learning activities and student learning outcomes tests. The result of the research Showed 1) the average student motivation was $88.13 \%$ with a very effective category, 2) the average student learning activity was $78.7 \%$ with an effective category and 3 ) the average student learning outcomes was $85.03 \%$ with effective categories.
\end{abstract}

Keywords: Practical Guide, Guided Inquiry, Plant Morphology.

\section{INTRODUCTION}

Education is expected to provide an opportunity for students to experience the four pillars of education is learning to know, learning to do, learning to live together and learning to be (UNESCO in Novalianti, 2012: 16). Education is not only focused on the mastery of the material, but also focused on the acquisition of skills. Science teacher now required to understand the discovery process involving the concept of fundamental skills through scientific experiments carried out through practical activities. Practicum is a laboratory activities to support science learning. So as a student teacher candidates requires the practice of direct application of the theory that the failure by to get a better sense of a material being studied. Practicum can bring students to experience the process of thinking, of this activity the students face to face with a problem related to the material being studied and given a chance to solve the problem. Practicum provides students the opportunity to prove the theory, finding a theory, or evaluating theories with guiding aids proper lab.

At the Institut Pendidikan Tapanuli Selatan Padangsidimpuan there are still some problems concerning the implementation of the practical one of which is in the subject of plant morphology are practical handbook that is still to be verified with the model instructions resep. Verification laboratory activities that are not much help in the development of thinking skills of students according to Kanter, 2003: 4. In line with the opinions Krisnawati (2006: 3), that the use of the procedure practicum verification and conventional lead students do not understand the real of practical activities, because they just do steps in accordance with the command. As a result of scientific attitudes skills students do not develop optimally. This makes the student feel practicum more emphasis on results and not on process. Plant morphology practical handbook used at the Institute of Education of South Tapanuli Padangsidimpuan yet oriented guided inquiry that has yet practical handbook steps of scientific activities involving optimally throughout the students' ability to seek and investigate something systematically, critically, logically and analytically. That makes the students can formulate its own discovery well.

To optimize student practicum courses in plant morphology has made various efforts, one of which is to design a practical handbook using inquiry approach. Inquiry means learning activities that involve maximally throughout the student's ability to investigate and find a systematic, critical, logical, analytical, so that students can find their own findings with aplomb (Mince: 2011). The selected inquiry mode is guided inquiry.

At this time guiding practical oriented guided inquiry is expected to help students find the concept and develop the students' scientific work. Hofsteins and Rachel (2007: 105) have the same opinion that, practicum using inquiry has the potential to develop the skills and science skills of students as being scientific in orienting questions, 
formulate hypotheses, designing, conducting research, collecting data and reviewing the scientific explanation, Because the activities of inquiry provide a meaningful context for the students to acquire, clarify, and apply an understanding of the concepts of science (tRNA, 2012). The above statement is reinforced by Brickman, et al., (2009: 3),

This is consistent with the results of study conducted by Khan and Iqbal (2011), that the inquiry learning by using laboratory can develop ideas and skills of students by placing students actively participate in the learning process are faced with problem situations in everyday life. In line with the opinion (Mustachfidoh, 2013), inquiry learning laboratory helps learners to integrate concepts they already know the events they observed in the laboratory.Aligned to the research conducted by Manzoor (2009), that the inquiry approach to teaching by making students interested in discovering the hypothesis of experimental results. By inquiry students can also find the concept of the experimental results and overcome the difficulties and obstacles for doing lab activities.

\section{METHODS}

This type of research is the development of research (Research and development). This study uses a model of development which is adapted from a model developed by Prof. Tjeerd Plomp from the University of Twenty, Eschede, Netherlands known as a research model Plomp. Based Plomp and Nieveen (2013: 30), research Plomp model development consists of three stages: 1. Initial Investigation Stage 2. Stage development or prototyping 3. Stages assessment.

\subsection{Early Stages of Investigation}

This phase aims to get an idea of karakteristis product being developed and can be used in practical activities. Tahapan- stage is a needs analysis, curriculum analysis, concept analysis, analysis of students, analysis of the material.

\subsection{Stage Prototyping}

Stages of development / prototyping is a practical guide product development stage plant morphology oriented guided inquiry followed by a formative evaluation aimed at enhancing and improving the quality of the products developed. Things that will be conducted by researchers at the stage of development that guides the writing lab terbimbingdan inquiry-oriented plant morphology lab validation guidance by experts / specialists and then revised.

\section{3 stages Ratings}

Stages of assessment is a summative evaluation stage semi- aimed to determine the actual effectiveness of the products that have been produced at the stage of development and prototyping. Ditahapan semi- summative evaluation is done in the form of a large group trial against the students of the Institute of Education of South Tapanuli Padangsidimpuan. At this stage of the assessment is to be assessed is the effectiveness of plant morphology oriented practical guide inkuir guided done Institt South Tapanuli Education majoring in biology education Padangsidimpuan third semester with the number of learners 24. Results seen the effectiveness of student learning motivation.

\section{RESULT AND DISCUSSION}

Student motivation in carrying out the activity of practicum. Student motivation is measured using questionnaires given to student motivation. Results of student motivation on lab activities guided inquiry-oriented plant morphology can be seen in Table 1.

Table 1. Values In Doing Practicum Student Motivation

\begin{tabular}{|l|l|l|l|}
\hline No. & Ratedaspect & $\begin{array}{l}\text { Average } \\
\text { scores\% }\end{array}$ & Category \\
\hline 1 & $\begin{array}{l}\text { Interest / concern } \\
\text { (interenst) }\end{array}$ & 91.4 & highly motivated \\
\hline 2 & $\begin{array}{l}\text { Relevant } \\
\text { (relevance) }\end{array}$ & 87 & highly motivated \\
\hline 3 & $\begin{array}{l}\text { Hope / the } \\
\text { assurance } \\
\text { (expectancy) }\end{array}$ & 89 & highly motivated \\
\hline 4 & $\begin{array}{l}\text { Satisfaction } \\
\text { (satisfication) }\end{array}$ & 85 & highly motivated \\
\hline Average & 88.13 & highly motivated \\
\hline
\end{tabular}

Value aspects of interest in having the highest average of all aspects of $91.4 \%$ with a very high category. The high interest / attention of students because of the experience felt by the students at the time of formulating hypotheses and work step itself has its own impression for students. Students were interested and curious to prove the hypothesis formulation had made and tried to move sufficient work itself.

Relevant aspects of the value of as much as $87 \%$ with a very high category. It karenaka there is a match between the needs and conditions of the contents of guiding students toward keterkaiatan practicum with course materials. While the value of the aspect of hope / the assurance was $89 \%$ with a very high category. Aspects of hope / the assurance contains about expectations of students on lab activities that use practical guide oriented guided inquiry. While aspects of the practicum student satisfaction by using guided inquiry-oriented practical guide has a value of $85 \%$ with a very high category.

The average aspect of students' learning motivation is $88.13 \%$ Category of very high and very motivated with a very effective criteria. This means practical guide 
developed to attract interest and motivation of students to carry out practical work. Woolnoug and Allsop (Sham and Dede, 2007: 8) states, the motivation to learn science lab.

\subsection{Analysis of Student Activities}

Activities students during practicum using practical guidance-oriented plant morphology observed inkuir guided by three faculty as an observer. The observed activity is focused on five aspects. The observations on each aspect can be seen in Table 2

Table 2. Observations of Student Activities

\begin{tabular}{|l|l|l|l|l|l|l|}
\hline No & $\begin{array}{l}\text { Aspects of } \\
\text { student } \\
\text { activity } \\
\text { observatio } \\
\text { n }\end{array}$ & \multicolumn{2}{|l|}{$\begin{array}{l}\text { Scores } \\
\text { activity observation }\end{array}$} & $\begin{array}{l}\text { Averag } \\
\text { e } \\
\text { scores } \\
(\%)\end{array}$ & $\begin{array}{l}\text { Categ } \\
\text { ory }\end{array}$ \\
\cline { 2 - 6 } & $\begin{array}{l}\text { Prak } \\
1\end{array}$ & $\begin{array}{l}\text { Prak } \\
2\end{array}$ & $\begin{array}{l}\text { Prak } \\
3\end{array}$ & & \\
\hline 1. & $\begin{array}{l}\text { Develop } \\
\text { practical } \\
\text { steps }\end{array}$ & 66.6 & 75 & 91.6 & 77.7 & $\begin{array}{l}\text { Effect } \\
\text { ive }\end{array}$ \\
\hline 2. & $\begin{array}{l}\text { Doing lab } \\
\text { activities } \\
\text { in } \\
\text { accordance } \\
\text { with the } \\
\text { working } \\
\text { steps that } \\
\text { have been } \\
\text { prepared. }\end{array}$ & 79 & 83.3 & 91.6 & 84.6 & $\begin{array}{l}\text { Effect } \\
\text { ive }\end{array}$ \\
\hline 3. & $\begin{array}{l}\text { Were } \\
\text { active in } \\
\text { lab } \\
\text { activities }\end{array}$ & 62.5 & 75 & 87 & 74.8 & $\begin{array}{l}\text { Effect } \\
\text { ive }\end{array}$ \\
\hline 4. & $\begin{array}{l}\text { Viewing } \\
\text { the results } \\
\text { of lab } \\
\text { carefully } \\
\text { soccording } \\
\text { to the } \\
\text { results of } \\
\text { lab } \\
\text { conclusion }\end{array}$ & 66.6 & 79.1 & 83.3 & 76.3 & $\begin{array}{l}\text { Effect } \\
\text { ive }\end{array}$ \\
\hline Average & $\begin{array}{l}\text { Make } \\
\text { abe }\end{array}$ & & \\
\hline
\end{tabular}

Preparing their practicum work properly obtain the value of $77.7 \%$ with an effective category. This is due to the strong desire of students to arrange their own work steps in practical activities. Students were competing in preparing their work as soon as possible in order to make observations.

Doing lab activities in accordance with the working steps that have been developed have a value of $84.7 \%$ is very effective denagn category. While the value of actively involved in the practicum has a value of $74 \%$ with an effective category, this aspect was the lowest of the other aspects. This is because the ability of different students in one group. This leads all active students in practical activities, so that no visible support them alone and just sit still see the theme being practical.

Viewing the results of lab carefully has a value $76.3 \%$ with effective category. And lastly make conclusions consistent with the observation that $80.5 \%$ categorized as very effective. This is because students already have high thoughts and be able to analyze the problem posed. Sanjaya (1010: 62) states, students can draw conclusions indicate that students have a high level of thinking for drawing conclusions is the linking process some information so that it appears a concept in the form of a conclusion.

The average value of the 3 practicum student activity undertaken is $78.7 \%$. This shows that the activity of the student during lab activities using plant morphology practical guide oriented guided inquiry included in the category of effective it can be said good practical guide and can be used in practical activities.

\subsection{Student Learning Outcomes}

The learning result obtained in this study derived from the test at the end of the practicum. This test was conducted to assess the cognitive abilities of the students after the lab using practical guidance guided inkuir oriented plant morphology. Recapitulation student results are shown in Table. 3.

Table 3. Results of Student Learning

\begin{tabular}{|l|l|l|l|l|}
\hline No. & Student name & Score & L / TL & Category \\
\hline 1 & $\begin{array}{l}\text { Ainun Mardiah } \\
\text { Siregar }\end{array}$ & 77.7 & Graduated & Effective \\
\hline 2 & $\begin{array}{l}\text { Aisha Ainil } \\
\text { Mardiah }\end{array}$ & 81.5 & Graduated & Effective \\
\hline 3 & $\begin{array}{l}\text { Synergy Aryani } \\
\text { Sihotang }\end{array}$ & 81.5 & Graduated & Effective \\
\hline 4 & $\begin{array}{l}\text { Bethesda Sari } \\
\text { Marcaret S }\end{array}$ & 88.8 & Graduated & $\begin{array}{l}\text { Very } \\
\text { effective }\end{array}$ \\
\hline 5 & $\begin{array}{l}\text { Dian Erwira } \\
\text { Harahap }\end{array}$ & 81.5 & Graduated & Effective \\
\hline 6 & $\begin{array}{l}\text { Elvita Sari } \\
\text { Harahap }\end{array}$ & 85.2 & Graduated & Effective \\
\hline 7 & $\begin{array}{l}\text { F.Dianalewisky } \\
\text { Ritonga }\end{array}$ & 88.8 & Graduated & $\begin{array}{l}\text { Very } \\
\text { effective }\end{array}$ \\
\hline 8 & $\begin{array}{l}\text { Hasmainun } \\
\text { Siregar }\end{array}$ & 88.8 & Graduated & $\begin{array}{l}\text { Very } \\
\text { effective }\end{array}$ \\
\hline 9 & Juwita Harahap & 88.8 & Graduated & $\begin{array}{l}\text { Very } \\
\text { effective }\end{array}$ \\
\hline 10 & Listian Ritonga & 85.2 & Graduated & Effective \\
\hline
\end{tabular}




\begin{tabular}{|c|c|c|c|c|}
\hline 11 & $\begin{array}{l}\text { Maiya } \\
\text { Rahmadani } \\
\text { Siregar }\end{array}$ & 85.2 & Graduated & Effective \\
\hline 12 & $\begin{array}{l}\text { Mega Monika } \\
\text { Sinaga }\end{array}$ & 85.2 & Graduated & Effective \\
\hline 13 & $\begin{array}{l}\text { Nur Halimah } \\
\text { Rangkuti }\end{array}$ & 85.2 & Graduated & Effective \\
\hline 14 & $\begin{array}{l}\text { Nur Hadimah } \\
\text { Samosir }\end{array}$ & 85.2 & Graduated & Effective \\
\hline 15 & $\begin{array}{l}\text { Remsiana } \\
\text { Rambe }\end{array}$ & 85.2 & Graduated & Effective \\
\hline 16 & $\begin{array}{l}\text { Riska Hasbiah } \\
\text { Lubis }\end{array}$ & 88.8 & Graduated & $\begin{array}{l}\text { Very } \\
\text { effective }\end{array}$ \\
\hline 17 & $\begin{array}{l}\text { Risky Amaliah } \\
\text { HSB }\end{array}$ & 92.6 & Graduated & $\begin{array}{l}\text { Very } \\
\text { effective }\end{array}$ \\
\hline 18 & $\begin{array}{l}\text { Risky Harahap } \\
\text { Agustina }\end{array}$ & 92.6 & Graduated & $\begin{array}{l}\text { Very } \\
\text { effective }\end{array}$ \\
\hline 19 & Rodiah Lubis & 85.2 & Graduated & Effective \\
\hline 20 & $\begin{array}{l}\text { Rodiana } \\
\text { Simbolon }\end{array}$ & 81.5 & Graduated & Effective \\
\hline 21 & $\begin{array}{l}\text { Siti Hartati } \\
\text { Pardede }\end{array}$ & 77.7 & Graduated & Effective \\
\hline 22 & $\begin{array}{l}\text { Women } \\
\text { Tukmaida } \\
\text { Pohan }\end{array}$ & 77.7 & Graduated & Effective \\
\hline 23 & Widiah & 81.5 & Graduated & Effective \\
\hline 24 & Rahmat Amin & 81.5 & Graduated & Effective \\
\hline \multicolumn{2}{|c|}{ Total } & 2040.8 & & \\
\hline \multicolumn{2}{|c|}{ Average } & 85.03 & Graduated & Effective \\
\hline
\end{tabular}

Student results obtained an average of $85.03 \%$ and effective category. This is due to increased student learning outcomes after using pilot plant morphology lab derorientasi guided inquiry. Students who pass reach $100 \%$. This marks the students have grasped the material already presented in the pilot plant morphology lab and could answer the test well. According Riduwan (2009: 88), a class is said to be complete study if $\geq 85 \%$ of the students have completed their study. So we can conclude pilot plant morphology lab oriented guided inquiry being used has been to improve learning outcomes of students with effective category.

\section{CONCLUSION}

Based on the development of research that has been done, has produced practical guidance plant morphology oriented guided inquiry for students of biology education effective. Effectiveness modules views of $88.13 \%$ category learning motivation is very high motivation, learning activity category $78.85 \%$ effective, and learning outcomes on average $85.03 \%$ effective category.

\section{REFERENCES}

[1] Brickman, P, Gormally, C, Hallar, B \& Armstrong, N. (2011). Lessons learnedbout implementing an inquiry-based curriculum in a college classroom biologylaboratory. Journal of College Science Teaching, 40 (3), 45-51.

[2] Chin, C \& Chia, L. 2005. Problem-based learning: Using ill-structured problem inbiology project work. Science Education, 90 (1): 44-67

[3] Kanter et al. Inquiry-Bsed 2003. Laboratory Instruction Throws Out the "Cookbook" and Improves Learning. Proceedings of the 2003 American Society for Engineerring Annual Conference \& Exposition. Session 2230.

[4] Khan, M., \& Iqbal, MZ, 2011. "Effects of Inquiry Teaching Method Lab on the Development of Scientific Skills through the Teaching of Biology in Pakistan." Strength for Today and Bright Hope for Tomorrow Journal, 11 (1), 169- 178.

Krisnawati, H. 2006. Keterampilan Proses Sains Siswa SMP dalam Praktikum Berbasis Guided Inguiri pada Sub Konsep Pencemaran Tanah Jurusan FMIPA UPI.Bandung: Tidak Diterbitkan.UPI

[6] Kusnadi dan yanti. 2008. Profil Keterampilan Proses Sains Mahasiswa Melalui Pembelajaran Berbasis Kerja Ilmiah Pada Mata Kuliah Mikrobiologi. Laporan Penelitian. Bandung: FMIPA UPI.

[7] Manzoor, AK 2009. Teaching of heat and tempe/rature by a hypothetical inquiry approach: A sample of Inquiry teaching. Of Pysics Teacher Education Journal Online. Vol. 5 (2): 43-64.

[8] Mince. 2011. Pengembangan Prangkat Pembelajaran Biologi MenggunakanModel Pembelajaran Inkuiri Untuk Meningkatkan Hasil Belajar SiswaPada Kelas XI IPA SMA Karuna Dipa Palu.Biodidaktis, 5 (1).

[9] Mustachfidoh, Swasta, I. B. J., \& Widiyanti, N. L. P. M.2013. Pengaruh Model 
Pembelajaran Inkuiri terhadap Prestasi

Belajar Biologi ditinjau dari Inteligensi Siswa

SMA Negeri 1 SRONO. e-Journal

ProgramPascasarjana Universitas Pendidikan

GaneshaProgram Studi Pendidikan IPA.

(Online), 3(1):2013,

(http://pasca.undiksha.ac.id/e-

journal/index.php/ jurnal_ipa/

article/view/542, diakses 19 september 2017.

[10] Novalianti. 2012. Implementasi Pendekatan

Empat Pilar Pendidikan UNESCO Pada Mata

Pelajaran Fiqih Kelas X DI MAN Rejosari

Madiun.SKRIPSI.Online. digilib.uinsby.ac.id. diakses oktober 2017.

[11] Plom, T and Nieveen, 2013. Desaign

Research.Enschede Education, University of

Twente.

[12] Sanjaya, W. 2006. Starategi Pembelajaran

Berorientasi Sandar Proses Pendidikan.Jakarta:

Kencana Prenada Media.

[13] Syam, H, dan Dede. 2007. Praktikum Inkuiri.

Makalah ( online): http//file UPI edu/ direktori/

Fmipa/ jur_pend_FISIKA/ BPF/ inquiri dan praktikum evadik, Pdf. Diakses tanggal 23 september 2017. 